\title{
Systematic Review \\ Efficacy of High-Dose Polyclonal Intravenous Immunoglobulin in COVID-19: A Systematic Review
}

\author{
Daniele Focosi $^{1}\left[\right.$, Massimo Franchini ${ }^{2, *} \mathbb{C}$, Marco Tuccori ${ }^{3,4}\left(\mathbb{D}\right.$ and Mario Cruciani ${ }^{2} \mathbb{C}$ \\ 1 North-Western Tuscany Blood Bank, Pisa University Hospital, 56124 Pisa, Italy; daniele.focosi@gmail.com \\ 2 Department of Hematology and Transfusion Medicine, Carlo Poma Hospital, 46100 Mantua, Italy; \\ crucianimario@virgilio.it \\ 3 Division of Pharmacology and Pharmacovigilance, University of Pisa, 56126 Pisa, Italy; \\ marco.tuccori@gmail.com \\ 4 Unit of Adverse Drug Reaction Monitoring, Pisa University Hospital, 56124 Pisa, Italy \\ * Correspondence: massimo.franchini@asst-mantova.it
}

check for updates

Citation: Focosi, D.; Franchini, M.; Tuccori, M.; Cruciani, M. Efficacy of High-Dose Polyclonal Intravenous Immunoglobulin in COVID-19: A Systematic Review. Vaccines 2022, 10, 94. https://doi.org/10.3390/ vaccines10010094

Academic Editor: S. Louise Cosby

Received: 8 December 2021

Accepted: 6 January 2022

Published: 9 January 2022

Publisher's Note: MDPI stays neutral with regard to jurisdictional claims in published maps and institutional affiliations.

Copyright: (c) 2022 by the authors. Licensee MDPI, Basel, Switzerland. This article is an open access article distributed under the terms and conditions of the Creative Commons Attribution (CC BY) license (https:// creativecommons.org/licenses/by/ $4.0 /)$.

\begin{abstract}
Background: Although several therapeutic strategies have been investigated, the optimal treatment approach for patients with coronavirus disease (COVID-19) remains to be elucidated. This systematic review and meta-analysis aimed to evaluate the efficacy and safety of polyclonal intravenous immunoglobulin (IVIG) therapy in COVID-19. Methods: A systematic literature search using appropriate medical subject heading $(\mathrm{MeSH})$ terms was performed through Medline (PubMed), EMBASE, SCOPUS, OVID and Cochrane Library electronic databases. The main outcomes considered were mortality and safety of IVIG versus placebo/standard of care. This review was carried out in accordance with Cochrane methodology including the risk bias assessment and grading of the quality of evidence. Measures of treatment effect were mean differences (MD) together with $95 \%$ confidence intervals (CIs) for continuous outcome measures and risk ratio (RR) or MD for binary outcomes. Two reviewers independently extracted data from individual studies, and disagreements were resolved by a third reviewer. Results: A total of 2401 COVID-19 patients from 10 studies (four randomized controlled trials (RCT) and six non-randomized controlled trials (non-RCTs)) were included in the analysis. Participants received IVIG or placebo/standard of care. The use of IVIG was not associated with a significantly reduced risk of death (RR 0.50, 95\% CIs $0.18-1.36, p=0.17$ for RCTs; RR 0.95, $95 \%$ CIs $0.61-1.58, p=0.94$ for non-RCTs; low certainty of evidence). IVIG significantly reduced the length of hospital stay (MD $-2.24,95 \%$ CIs $-3.20 /-1.27 ; p=0.00001$; low certainty of evidence), although this difference was significant only for studies evaluating moderate COVID-19 patients. No significant difference was observed in the incidence of overall and serious adverse events between IVIG recipients and controls (very low certainty of evidence). Conclusions: The current evidence from the literature does not support the use of IVIG in COVID-19 patients.
\end{abstract}

Keywords: intravenous immunoglobulins; polyclonal antibodies; immunosuppressants; COVID-19; SARS-CoV-2

\section{Introduction}

Severe acute respiratory syndrome coronavirus 2 (SARS-CoV-2) caused the coronavirus disease (COVID-19) pandemic beginning in 2019 [1,2]. At the time of writing, more than 4 million people have died from coronavirus disease (COVID-19), and more than 200 million have been infected [3]. Clinicians and researchers have struggled to develop an effective therapeutic protocol to treat and contain the spread of this infectious disease, and more than 300 drugs have been or are being investigated under clinical trials in different parts of the world [4,5]. Among the various therapeutic and prophylactic strategies developed to contain the COVID-19 epidemic, passive immunization by COVID-19 convalescent plasma (CCP) transfusion has been proven effective when CCP was administered early (within $72 \mathrm{~h}$ from symptom onset) and with a high titer ( $>1: 160)$ of anti-SARS-CoV-2 
neutralizing antibodies (nAb) [6,7]. Late disease stages are characterized by an exaggerated immune response, which responds to immunosuppressants: high-dose intravenous immunoglobulin (IVIG), based on previous positive experiences in autoimmune, inflammatory and other infectious diseases, including coronavirus-induced infections [8,9], has been also proposed for COVID-19 [10-13].

The aim of this review is to systematically analyze the safety and efficacy of the use of high-dose IVIG in patients with COVID-19 (including new primary research) and grade the quality of the available evidence following the Cochrane guidance for methodology.

\section{Material and Methods}

This systematic review was registered at the International Prospective Register of Systematic Reviews (PROSPERO) with the registration number CRD42021281233.

\subsection{Review Question/Objective}

The aim of this systematic review is to evaluate the clinical use of high-dose IVIG for the treatment of COVID-19 patients.

\subsection{Inclusion and Exclusion Criteria}

We included all randomized controlled trials (RCTs) and non-RCTs (i.e., prospective, retrospective, cross-sectional and cohort studies) evaluating the safety and efficacy of highdose IVIG in patients with COVID-19. We also planned to include controlled non-RCT, considering that only a small number of randomized trials was available. Case reports or case series were excluded from the analysis of this review, as well as studies evaluating hyperimmune IVIG against SARS-CoV-2 or IVIG in viral or other infectious diseases. Nonpeer reviewed or ongoing trials were not included in this systematic review, nor were non-comparative studies.

\subsection{Clinical Setting and Participants}

For this systematic review, we considered studies on COVID-19 at any stage of disease severity, from asymptomatic/paucisymptomatic to life-threatening cases. In addition, we included populations of patients with no limitations of age, gender, ethnicity or comorbidities.

\subsection{Intervention and Outcomes}

IVIG treatment at any dose, timing and frequency was evaluated. We planned to include, where available, the following outcomes: all-cause mortality, clinical improvement, serious and non-serious adverse reactions, length of hospital stay and discharge rate, admission to intensive care unit (ICU), length of ICU or hospital stay, need for invasive mechanical ventilation (IMV) and progression to severe disease and adverse events (overall and serious). Severe COVID-19 was defined as the presence of at least one of the following criteria: (1) radiologically confirmed pneumonia; (2) tachypnea with respiratory rate $\geq 30$ breaths / min; (3) oxygen saturation $(\mathrm{SpO} 2) \leq 93 \%$ at rest and in room air; and (4) partial pressure of oxygen $(\mathrm{PaO} 2) /$ fraction of inspired oxygen $(\mathrm{FiO} 2) \leq 300 \mathrm{mmHg}$.

\subsection{Search Methods}

For this systematic review we analyzed the medical literature for published articles on the use of IVIG in COVID-19 patients. A literature search of the MEDLINE (through PUBMED), EMBASE, SCOPUS, OVID and Cochrane Library electronic databases was carried out from 1 January 2020 to 31 August 2021, using English language as a restriction. Only articles published following a peer-reviewing process were included in the final analysis. The medical subject heading (MeSH) and key words used were: ("COVID-19" OR "SARS-CoV-2" OR “coronavirus disease 2019") AND ("IVIG" OR “immunoglobulin"). We also screened the reference lists of the most relevant review articles for additional studies not captured in our initial literature search. 


\subsection{Study Selection and Data Extraction}

All titles were screened by two independent reviewers (MC and MF). Eligibility assessment was based on the title or abstract and on the full text if necessary. Full texts of possibly eligible articles were evaluated independently by two reviewers (MC and MF). Studies were selected independently by two reviewers (MF and MC) with disagreements resolved by a third reviewer (DF). The two reviewers also independently extracted quantitative and qualitative data from each selected study (Table 1). Quantitative tabulation of results includes: first author name and year of publication, the type of the study, the disease severity, the population size (intervention and control groups), treatment (intervention and control groups), adverse reactions and main results.

\subsection{Assessment of the Methodological Quality of Published Clinical Studies}

Two review authors (MF, MC) independently assessed the risk of bias of each included study following the domain-based evaluation described in the Cochrane Handbook for Systematic Reviews of Interventions [14]. They discussed any discrepancies and achieved consensus on the final assessment.

We considered both RCTs and controlled non-RCT. Within-trial risk of bias was assessed, using the Cochrane ROB tool for RCTs and the ROBINS-I tool for non-RCTs. The Cochrane 'Risk of bias' tool for RCTs addresses six specific domains: sequence generation, allocation concealment, blinding, incomplete data, selective outcome reporting and other issues relating to bias. The methodological quality of observational studies was assessed with the ROBINS-1 tool [15-17]. This tool includes seven specific bias domains, pre-intervention and post-intervention, and it has to be performed as an outcome-based assessment for each outcome reported for a trial. The domains are: (1) confounding; (2) selection of participants; (3) classification of intervention; (4) deviation from interventions (biases that arise when there are systematic differences between the care provided to experimental intervention and comparator groups, beyond the assigned interventions); (5) missing outcome; (6) measurement of outcomes (blinding of outcome assessors aims to prevent systematic differences in measurements between intervention groups, but it is less common in non-RCTs than in RCTs; and (7) selection of reported result overall.

For both RCTs and non-RCTs we have presented our assessment of risk of bias using two 'Risk of bias' summary figures: (1) a summary of bias for each item across all studies; and (2) a cross-tabulation of each trial by all the 'Risk of bias' items.

\subsection{Effect of Intervention}

Measures of treatment effect were mean differences (MD) together with 95\% confidence intervals (CIs) for continuous outcome measures and risk ratio (RR) or MD for binary outcomes. When necessary, disagreement was resolved by consensus and by a third reviewer (DF). For continuous measures, the score had to be reported as mean and standard deviation (SD); when reports provided medians and interquartile range, pooling of data was not performed.

The study weight was calculated using the Mantel-Haenszel method. We assessed statistical heterogeneity using $\mathrm{t}^{2}$, Cochran's $\mathrm{Q}$ and $I^{2}$ statistics [18]. The $I^{2}$ statistic describes the percentage of total variation across trials due to heterogeneity rather than sampling error. In the case of no heterogeneity $\left(I^{2}=0\right)$, studies were pooled using a fixed-effects model. When values of $I^{2}$ were $>0$, a random-effects analysis was undertaken.

\subsection{Subgroup Analyses}

We anticipated heterogeneity in the design and reporting of studies and, to deal with heterogeneity, we planned to carry out subgroup analyses of the outcomes "mortality" and "length of hospital stay" in treatment control groups according to baseline clinical conditions (e.g., moderate vs. severe COVID-19). 


\subsection{0. 'Summary of Findings' Tables}

We used the principles of the GRADE system to assess the quality of the body of evidence associated with specific outcomes and constructed 'Summary of findings' tables using REVMAN 5.4 (The Cochrane Collaboration, London, UK) $[19,20]$. These tables present key information concerning the certainty of the evidence, the magnitude of the effects of the interventions examined and the sum of available data for the main outcomes. The 'Summary of findings' tables also include an overall grading of the evidence related to each of the main outcomes using the GRADE approach, which defines the certainty of a body of evidence as the extent to which one can be confident that an estimate of effect or association is close to the true quantity of specific interest. The certainty of a body of evidence involves consideration of within-trial risk of bias (methodological quality), directness of evidence, heterogeneity, precision of effect estimates, and risk of publication bias. We have presented the following outcomes in the 'Summary of findings' table: (i) mortality; (ii) length of hospital stay and (iii) adverse events. All calculations were conducted using REVMAN 5.4 .

\section{Results}

Electronic and manual searches yielded 674 potentially relevant studies (Figure 1). Six hundred and seven articles were excluded after preliminary screening. The remaining 67 articles were deemed potentially eligible, and their full text was assessed. Fifty-five articles were then excluded because of case series or case reports, protocols or because they did not meet the inclusion criteria. Two additional studies were excluded because, although they focused on IVIG use in COVID-19 patients, they were not controlled trials [21,22]. Thus, for this systematic review we considered 10 studies fulfilling our pre-specified criteria, including 2401 COVID-19 patients [23-32]. Four studies were RCT [25,29,30,32], and six studies were non-RCT (all retrospective) [24,26-28,31,32]. Five studies were conducted in China, two in Iran and one each in India, the USA and Turkey. In two studies, IVIG use was restricted to non-severe COVID-19 cases [27,29], while in the other eight trials IVIGs were used in severe or critical patients. Table 1 summarizes the main characteristics and results of these studies. The dosage and timing of IVIG administration was greatly variable between studies. The comparator group included standard therapy (nine studies) or placebo (one study) [25].

\subsection{Risk of Bias in Included Studies}

Of the four RCTs, three were at high risk of performance (open-label trials), three were at unclear risk of detection bias (because it was unclear whether the assessors were blinded to treatment allocation) and two at unclear risk of selection bias (because no clear information on allocation concealment were provided) (Supplementary File S1). According to the ROBINS-I tool, for the outcome mortality, four non-RCTs were judged to be at high risk of confounding bias, and two at unclear risk (Supplementary File S1). For selection bias, three non-RCTs were judged to be at high risk, and one at unclear risk. All the non-RCTs were judged to be at unclear risk of bias for the domain bias in measurement "classification of interventions" due to the retrospective nature of these studies.

\subsection{Effects of Interventions}

A summary of the outcomes reported in the included study is provided in Table 1 and the Supplementary File S1 (Data and Analyses). The most commonly reported outcomes were mortality and length of hospital stay (Figures 2 and 3). For the other outcomes (see the Supplementary File S1), it was not possible to perform a pooled analysis because they were inconsistently reported or because, for continuous variables, values were reported as median and interquartile range. 


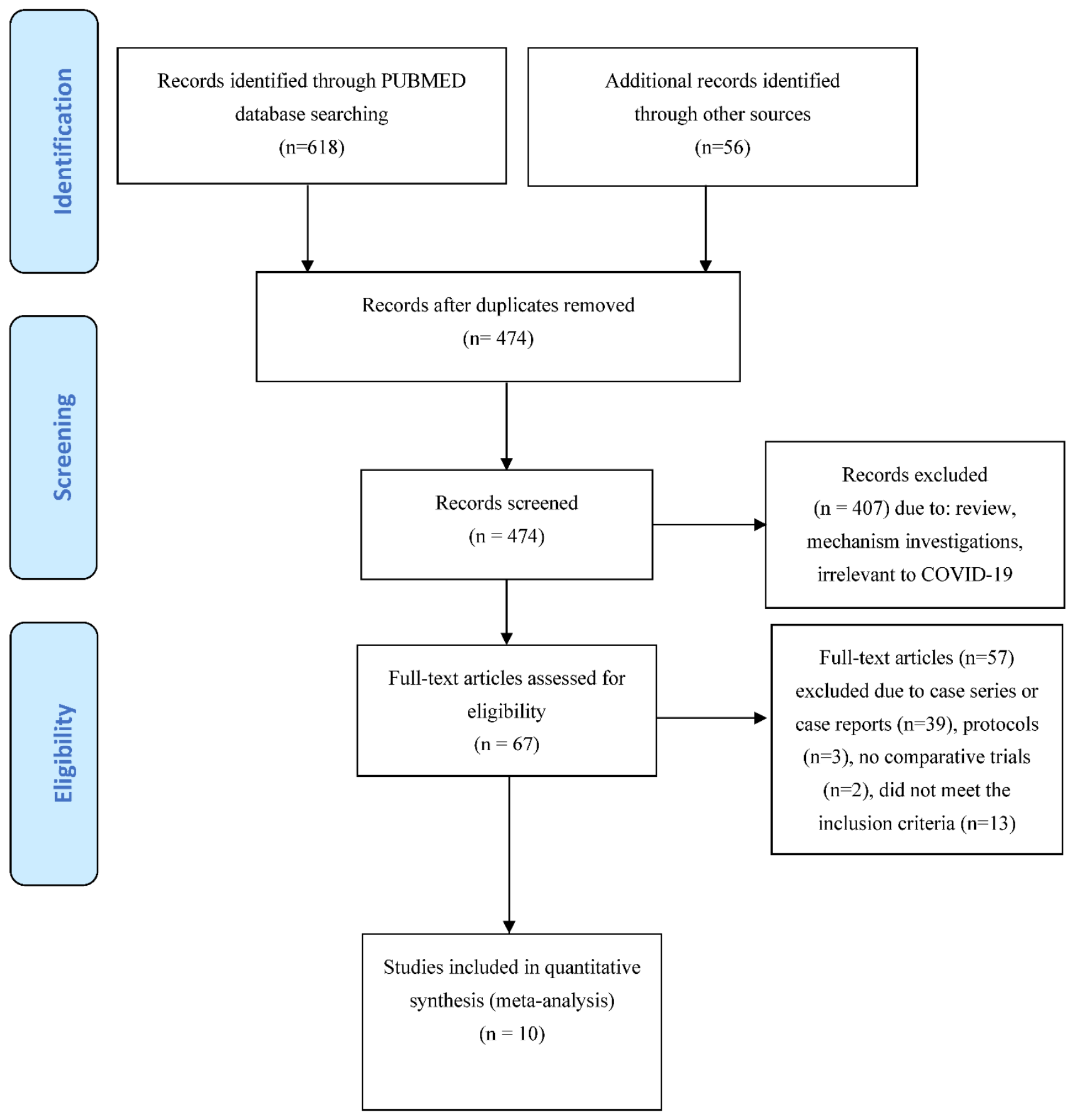

Figure 1. PRISMA flow diagram of study selection. 
Table 1. Characteristics of the studies included.

\begin{tabular}{|c|c|c|c|c|c|c|c|c|c|}
\hline $\begin{array}{l}\text { First Author, } \\
\text { Year [Ref.] }\end{array}$ & Type of Study & Disease Severity & $\begin{array}{l}\text { Population Size } \\
\text { (Intervention/ } \\
\text { Control) }\end{array}$ & $\begin{array}{c}\text { Single IVIG Dose per } \\
\text { Day } \\
\text { (Intervention/ } \\
\text { Control) }\end{array}$ & Duration (Days) & $\begin{array}{l}\text { Cumulative } \\
\text { Dose }\end{array}$ & Control & Safety & Main Results \\
\hline $\begin{array}{c}\text { Cao, } \\
2021 \text { [23] }\end{array}$ & RCS & $\begin{array}{c}\text { Severe } \\
\text { COVID-19 }\end{array}$ & $26 / 89$ & $0.4-1 \mathrm{~g} / \mathrm{kg}$ & $2-5$ days & $2 \mathrm{~g} / \mathrm{kg}$ & ST & No AEs & $\begin{array}{c}\text { High-dose IVIG reduced 28-day } \\
\text { mortality (HR } 0.24,95 \% \text { CI } 0.06-0.99 ; p< \\
0.001 \text { ). Early treatment (within } 7 \text { days of } \\
\text { onset) was associated with greater benefit }\end{array}$ \\
\hline $\begin{array}{c}\text { Esen, } \\
2021 \text { [24] }\end{array}$ & RCS & $\begin{array}{c}\text { Severe } \\
\text { COVID-19 }\end{array}$ & $51 / 42$ & $0.4 \mathrm{~g} / \mathrm{kg}$ * & 5 days & $2 \mathrm{~g} / \mathrm{kg}$ & ST & NR & $\begin{array}{c}\text { IVIG significantly prolonged median } \\
\text { survival time (68 versus } 18 \text { days, } p= \\
0.014)\end{array}$ \\
\hline $\begin{array}{l}\text { Gharebaghi, } \\
2020[25]\end{array}$ & $\mathrm{RCT}$ & $\begin{array}{c}\text { Severe } \\
\text { COVID-19 }\end{array}$ & $30 / 29$ & $0.3 \mathrm{~g} / \mathrm{kg}$ * & 3 days & $0.9 \mathrm{~g} / \mathrm{kg}$ & placebo & NR & $\begin{array}{l}\text { IVIG significantly reduced mortality rate } \\
\text { (aOR } 0.003,95 \% \text { CI } 0.001-0.815 ; p=0.042)\end{array}$ \\
\hline $\begin{array}{c}\text { Hou, } \\
2021 \text { [26] }\end{array}$ & RCS & $\begin{array}{c}\text { Severe } \\
\text { COVID-19 }\end{array}$ & $47 / 66$ & $0.5 \mathrm{~g} / \mathrm{kg}$ & NR & NR & ST & NR & $\begin{array}{l}\text { IVIG did not improve in-hospital } \\
\text { mortality rates or the need for } \\
\text { mechanical ventilation }\end{array}$ \\
\hline \multirow{4}{*}{$\begin{array}{l}\text { Huang, } \\
2021[27]\end{array}$} & \multirow{4}{*}{ RCS } & \multirow{4}{*}{$\begin{array}{l}\text { Non-severe } \\
\text { COVID-19 }\end{array}$} & \multirow{4}{*}{$45 / 594$} & $0.13 \mathrm{~g} / \mathrm{kg}$ (8 patients) ${ }^{*}$ & 3 days & $0.5 \mathrm{~g} / \mathrm{kg}$ & \multirow{4}{*}{ ST } & \multirow{4}{*}{ NR } & \multirow{4}{*}{$\begin{array}{l}\text { No benefit was observed with IVIG in } \\
\text { terms of mortality rate, progression to } \\
\text { severe disease or length of hospital stay }\end{array}$} \\
\hline & & & & $0.13 \mathrm{~g} / \mathrm{kg}$ (13 patients) * & 5 days & $0.7 \mathrm{~g} / \mathrm{kg}$ & & & \\
\hline & & & & $0.26 \mathrm{~g} / \mathrm{kg}$ (16 patients) * & 3 days & $0.8 \mathrm{~g} / \mathrm{kg}$ & & & \\
\hline & & & & $0.26 \mathrm{~g} / \mathrm{kg}$ (8 patients) ${ }^{*}$ & 5 days & $1.3 \mathrm{~g} / \mathrm{kg}$ & & & \\
\hline $\begin{array}{c}\text { Liu, } \\
2021[28]\end{array}$ & RCS & $\begin{array}{c}\text { Severe } \\
\text { COVID-19 }\end{array}$ & $421 / 429$ & $0.13 \mathrm{~g} /$ day & 9.5 days & $1.3 \mathrm{~g} / \mathrm{kg}$ & ST & NR & $\begin{array}{l}\text { IVIG was not associated with significant } \\
\text { changes in 28-day mortality in severe } \\
\text { COVID-19 patients }\end{array}$ \\
\hline $\begin{array}{l}\text { Raman, } \\
2021[29]\end{array}$ & $\mathrm{RCT}$ & $\begin{array}{l}\text { Non-severe } \\
\text { COVID-19 }\end{array}$ & $50 / 50$ & $0.4 \mathrm{~g} / \mathrm{kg}$ & 5 days & $2 \mathrm{~g} / \mathrm{kg}$ & ST & $\begin{array}{l}17(34 \%) \\
\text { mild to } \\
\text { moderate }\end{array}$ & $\begin{array}{c}\text { Duration of hospital stay was } \\
\text { significantly lower in IVIG group ( } 7.7 \mathrm{vs.} \\
17.5 \text { days, } p=0.0001)\end{array}$ \\
\hline $\begin{array}{l}\text { Sakoulas, } \\
2020[30]\end{array}$ & $\mathrm{RCT}$ & $\begin{array}{c}\text { Severe } \\
\text { COVID-19 }\end{array}$ & $16 / 17$ & $0.5 \mathrm{~g} / \mathrm{kg}$ & 3 days & $1.5 \mathrm{~g} / \mathrm{kg}$ & ST & No AEs & $\begin{array}{l}\text { IVIG improved hypoxia and reduced } \\
\text { hospital length of stay and progression to } \\
\text { mechanical ventilation }\end{array}$ \\
\hline $\begin{array}{c}\text { Shao, } \\
2020[31]\end{array}$ & RCS & $\begin{array}{l}\text { Severe or critical } \\
\text { COVID-19 }\end{array}$ & $174 / 151$ & $\begin{array}{l}0.1 \mathrm{~g} / \mathrm{kg} \text { (100 patients) } \\
0.5 \mathrm{~g} / \mathrm{kg} \text { (74 patients) }\end{array}$ & $\begin{array}{l}5-15 \text { days (not } \\
\text { specified } \\
\text { according to } \\
\text { daily dose) }\end{array}$ & $\begin{array}{l}0.5-5 \mathrm{~g} / \mathrm{kg} \text { (not } \\
\text { specified } \\
\text { according to } \\
\text { daily dose) }\end{array}$ & ST & NR & $\begin{array}{c}\text { Early administration }(\leq 7 \text { days after } \\
\text { hospital admission) with high dose }(>15 \\
\text { g/day) of IVIG significantly reduced } \\
\text { 60-day mortality }\end{array}$ \\
\hline $\begin{array}{l}\text { Tabarsi, } \\
2021 \text { [32] }\end{array}$ & RCT & $\begin{array}{c}\text { Severe } \\
\text { COVID-19 }\end{array}$ & $52 / 32$ & $0.4 \mathrm{~g} / \mathrm{kg}$ & 3 days & $1.2 \mathrm{~g} / \mathrm{kg}$ & ST & NR & $\begin{array}{l}\text { No benefit was observed with IVIG in } \\
\text { terms of mortality rate and need for } \\
\text { mechanical ventilation }\end{array}$ \\
\hline
\end{tabular}




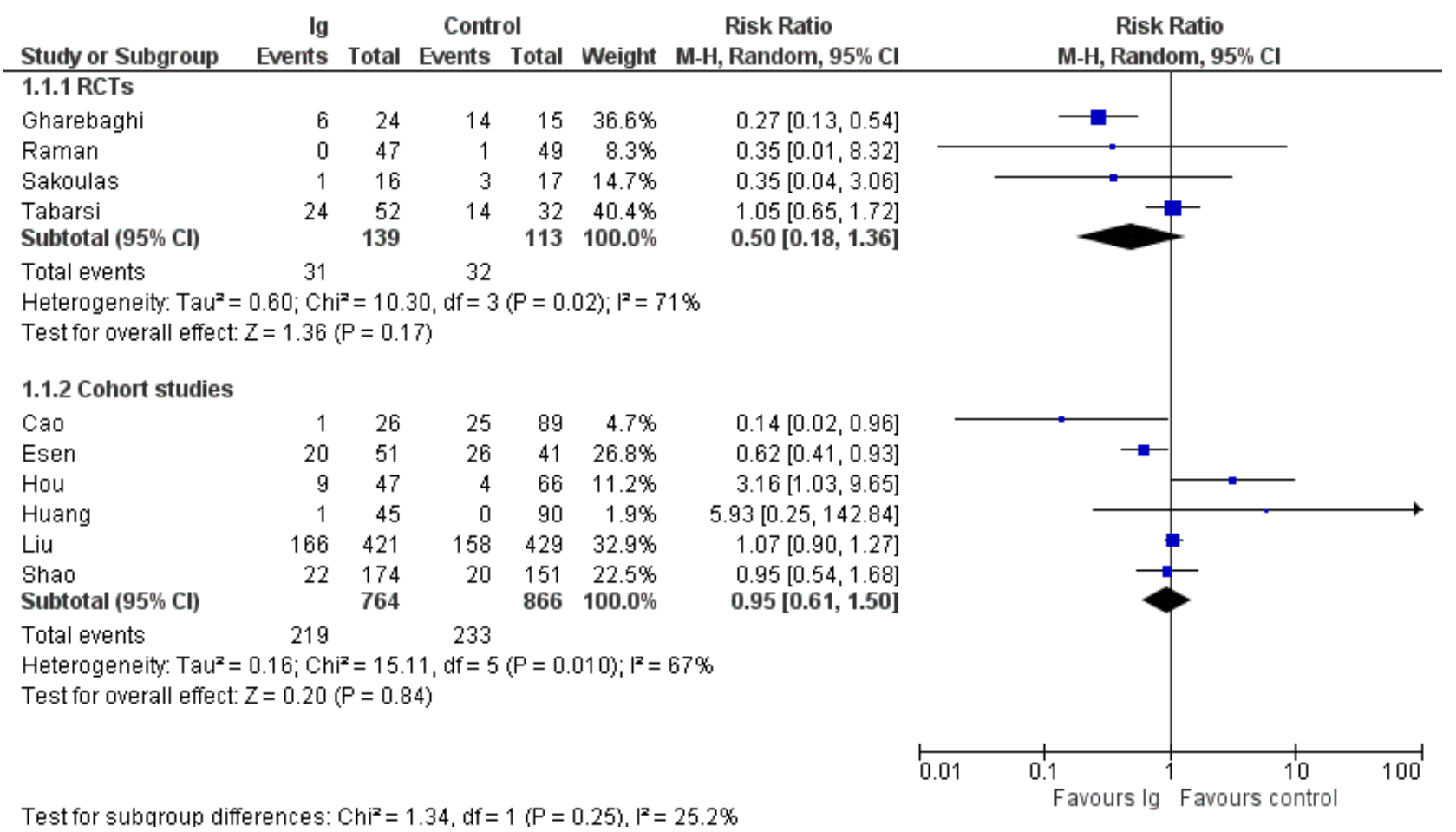

Figure 2. Forest plot of mortality.

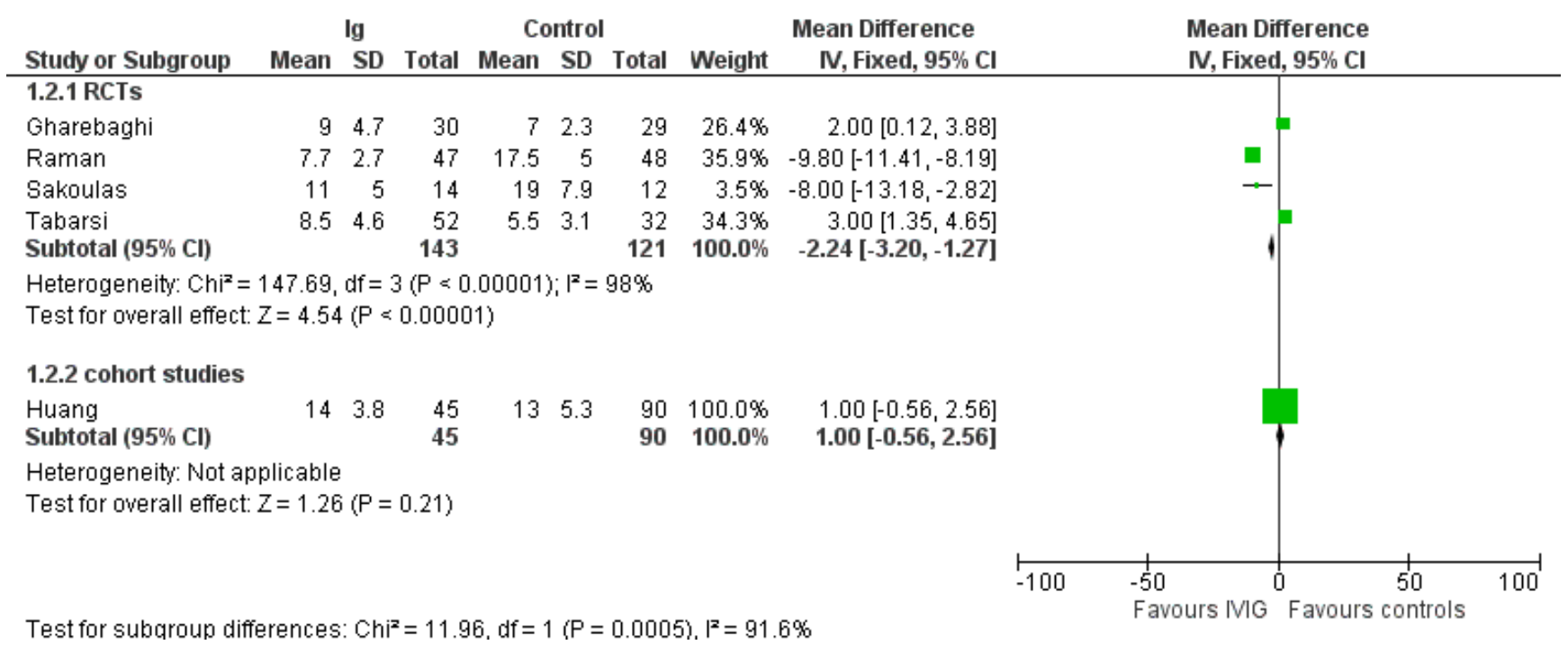

Figure 3. Forest plot of length of hospital stay.

\subsection{Mortality}

Data on mortality were reported in all 10 trials included in the review. In the four RCTs, there were 31 deaths out of 139 patients in the IVIG group compared to 32/113 in the control group (risk ratio (RR), 0.50; 95\% CIs, 0.18/1.36; $p=0.17$ ) (Figure 2); in the six non RCTs, there were 219 deaths out of 764 patients in IVIG group compared to 233/866 in the control group (RR, 0.95; 95\% CIs, 0.61/1.58; $p=0.94)$. In both cases the level of certainty was low due to imprecision and inconsistency. The subgroup analysis (see Supplementary File S2) according to the baseline conditions did not show differences in mortality rates in studies conducted in patients with moderate COVID-19 and in patients with severe/critical illness, both in RCTs (low quality of evidence) or in non-RCTs (very low quality of evidence) (Table 2). 
Table 2. Summary of findings table.

\begin{tabular}{|c|c|c|c|c|c|c|}
\hline \multicolumn{7}{|c|}{ Immunoglobulin Compared with Standard Treatment for COVID-19 } \\
\hline \multicolumn{7}{|c|}{$\begin{array}{l}\text { Patient or Population: Adults with COVID-19 } \\
\text { Settings: Both Outpatients and Hospitalized pts } \\
\text { Intervention: IVIG } \\
\text { Comparison: Standard Treatment }\end{array}$} \\
\hline \multirow{3}{*}{ Outcomes } & \multicolumn{2}{|c|}{ Illustrative Comparative Risks * $(95 \% \mathrm{CI})$} & \multirow{3}{*}{$\begin{array}{l}\text { Relative Effect } \\
\quad(95 \% \text { CI })\end{array}$} & \multirow{3}{*}{$\begin{array}{l}\text { No. of Participants } \\
\text { (Studies) }\end{array}$} & \multirow{3}{*}{$\begin{array}{l}\text { Quality of the } \\
\text { Evidence } \\
\text { (GRADE) }\end{array}$} & \multirow{3}{*}{ Comments } \\
\hline & Assumed Risk & Corresponding Risk & & & & \\
\hline & Control & IVIG & & & & \\
\hline \multirow{5}{*}{$\begin{array}{l}\text { Mortality-RCTs } \\
\text { (28 days) }\end{array}$} & Overall populat & th COVID-19 & \multirow{5}{*}{$\begin{array}{l}\text { RR } 0.50(0.18 / 1.36) \\
\text { RR 0.35 (0.06/2.10) } \\
\text { RR 0.54 }(0.14 / 2.09)\end{array}$} & \multirow{5}{*}{$\begin{array}{l}252(4) \\
125(2) \\
111(2)\end{array}$} & \multirow{5}{*}{$\begin{array}{l}\oplus \oplus \ominus \ominus \\
\text { low }^{1}\end{array}$} & \multirow{5}{*}{$\begin{array}{l}\text { It is unclear whether IVIG reduces mortality } \\
\text { compared to standard treatment in the overall } \\
\text { populations of pts with COVID-19 or in } \\
\text { moderate or severe COVID-19 pts }\end{array}$} \\
\hline & Mean mortality was $28.3 \%$ & $14.5 \%(5.0 / 38.4 \%)$ & & & & \\
\hline & Mean mortality was $6.0 \%$ & $2.1 \%(0.3 / 12.54 \%)$ & & & & \\
\hline & High-risk population (pts & evere/critical disease) & & & & \\
\hline & Mean mortality was $59.5 \%$ & $32.1 \%(8.3 / 124.3 \%)$ & & & & \\
\hline \multirow[t]{2}{*}{ Mortality—Cohort studies } & \multicolumn{2}{|c|}{ Overall population with COVID-19 } & \multirow[t]{2}{*}{ RR $0.95(0.61 / 1.50)$} & \multirow[t]{2}{*}{$6(1630)$} & \multirow[t]{2}{*}{$\underset{\text { low }^{2}}{\oplus \oplus \ominus \ominus}$} & \multirow{2}{*}{$\begin{array}{l}\text { It is unclear whether IVIG reduces mortality } \\
\text { compared to standard treatment in COVID-19. } \\
\text { The differences were not significant in } \\
\text { subgroup analyses of pts with moderate or } \\
\text { severe disease either. }\end{array}$} \\
\hline & Mean mortality was $26.9 \%$ & $25.2 \%(16.4 / 40.3 \%)$ & & & & \\
\hline $\begin{array}{l}\text { Length of Hospital stay } \\
\text { (days) }\end{array}$ & $\begin{array}{l}\text { The mean hospital stay is } \\
12.25\end{array}$ & $10.1(9.05 / 10.98)$ & $\mathrm{RD}-2.24(-3.20 /-1.27)$ & $4(264)$ & $\underset{\text { low }^{2}}{\oplus \oplus \ominus \ominus}$ & $\begin{array}{l}\text { IVIG reduces LHS compared to standard } \\
\text { treatment. The effect was driven mostly by } \\
\text { inclusion of pts with moderate COVID-19 } \\
\text { infections. Indeed, in the } 2 \text { studies enrolling } \\
\text { severe pts (see Supplementary File S2), the } \\
\text { difference in LHS favored controls compared } \\
\text { to IVIG (RD, } 2.57 ; 95 \% \text { CIs, } 1.33 / 3.80 ; p< \\
0.0001 \text {; low quality of evidence), while in } \\
\text { studies evaluating moderate pts, the difference } \\
\text { favored IVIG compared to controls.(RR, }-9.64 ; \\
95 \% \text { Cis, }-11.18 /-8.1 ; p<0.00001 ; \text { low } \\
\text { quality of certainty) }\end{array}$ \\
\hline $\begin{array}{l}\text { Adverse events } \\
\text { - Overall AE }\end{array}$ & $\begin{array}{l}\text { The mean occurrence of } \mathrm{AE} \\
\text { was } 12.8 \%\end{array}$ & $12.5 \%(11.6 / 13.4 \%)$ & $\mathrm{RD}-0.03(-0.12 / 0.06)$ & $3(248)$ & $\underset{\text { very-low }}{\oplus \ominus \ominus \ominus}$ & $\begin{array}{l}\text { Mean occurrence of AE was similar in IVIG } \\
\text { recipients and controls }\end{array}$ \\
\hline \multirow[t]{2}{*}{ - Serious AE } & $\begin{array}{c}\text { The mean occurrence of } \\
\text { serious AE was } \\
5.9 \%\end{array}$ & $5.9 \%(5.5 / 6.3 \%)$ & RR $0.00(-0.04 / 0.04)$ & $4(848)$ & $\underset{\text { very-low }}{\oplus \ominus \ominus \ominus}$ & $\begin{array}{l}\text { Mean occurrence of serious AE was similar in } \\
\text { IVIG recipients and controls }\end{array}$ \\
\hline & \multicolumn{6}{|c|}{$\begin{array}{l}\text { * The basis for the assumed risk is the mean control group risk across studies. The corresponding risk (and its } 95 \% \text { confidence interval) was based on the assumed risk in the comparison } \\
\text { group and the relative effect of the intervention (and its 95\% CI). CI: Confidence interval; RR: Risk Ratio; RD, risk difference; AE, adverse events; IVIG, intravenous iommunoglobulin } \\
\text { GRADE Working Group grades of evidence. High quality: Further research is very unlikely to change our confidence in the estimate of effect. Moderate quality: Further research is likely } \\
\text { to have an important impact on our confidence in the estimate of effect and may change the estimate. Low quality: Further research is very likely to have an important impact on our } \\
\text { confidence in the estimate of effect and is likely to change the estimate. Very low quality: We are very uncertain about the estimate. }{ }^{1} \text { Downgraded for imprecision and inconsistency. } \\
\text { Downgraded for inconsistency and ROB. }{ }^{2} \text { Downgraded for imprecision and twice downgraded for serious ROB. }\end{array}$} \\
\hline
\end{tabular}




\subsection{Length of Hospital Stay}

In the four RCTs IVIG reduced length of hospital stay compared to controls (MD, -2.24 days; $95 \%$ CIs, $-3.20 /-1.27 ; p=0.00001$ ) (Figure 3). Low certainty of evidence was due to inconsistency and ROB. The effect was driven mostly by inclusion of patients with a moderate COVID-19 infection. Indeed, in the two studies enrolling severe patients (see Supplementary File S2), the difference in length of hospital stay favored controls compared to IVIG (MD, 2.57 days; 95\% CIs, 1.33/3.80; $p<0.0001$; low quality of evidence), while in studies evaluating moderate patients, the difference favored IVIG compared to controls (RR, $-9.64 ; 95 \%$ CIs, $-11.18 /-8.1 ; p<0.00001$; low quality of certainty) (Table 2). Only one non-RCT [27] was evaluated for length of hospital stay.

Pooled analyses of RCTs and non-RCTs for the outcomes mortality and length of hospital stay did not significantly affect the effect size of the intervention, and the heterogeneity in the overall analyses remained high (data not shown).

\subsection{Adverse Events}

A total of 6 out of 10 studies did not mention adverse events at all. Overall adverse events were reported in three trials $[23,29,30]$ and serious adverse events in four trials $[23,27,29,30]$ (Figure 4). Overall adverse events were reported in 17/92 patients receiving IVIG and 20/156 patients receiving standard therapy (risk difference (RD) -0.03 ; 95\% CIs, - 0.12/0.06; very low quality of evidence due to imprecision and serious risk of bias). Serious adverse events were rarely reported either in IVIG recipients (4/137) or controls (42/710) (RD, 0.00; 95\% CIs, -0.04/0.04; very low quality of evidence due to imprecision and serious risk of bias (Table 2 ).

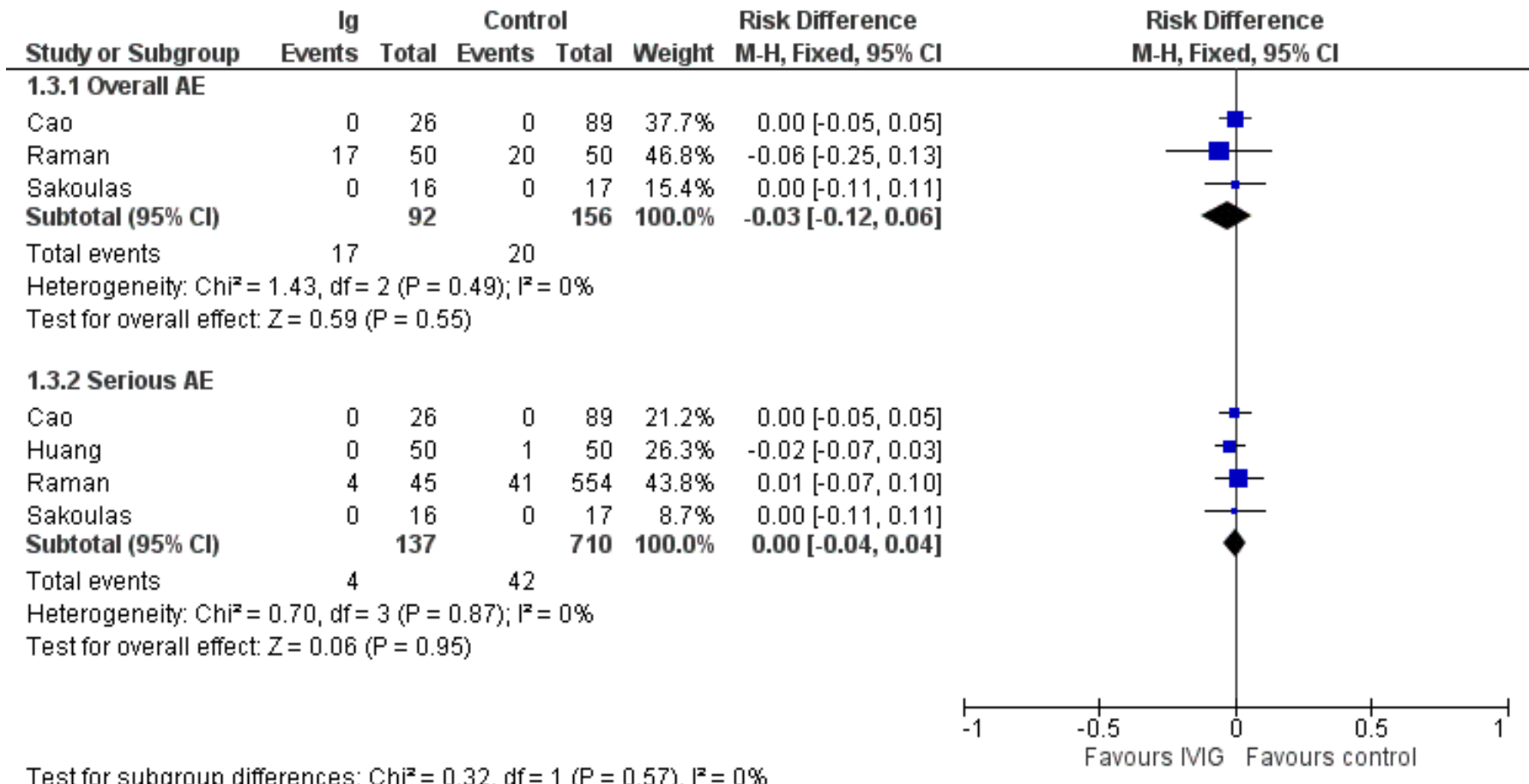

Figure 4. Forest plot of adverse events.

\section{Discussion}

Following the first trial demonstrating the efficacy of high-dose IVIG in patients with severe COVID-19 [23], other studies were conducted in this setting to assess the impact of IVIG on various clinical outcomes, mainly on mortality. High-dose polyclonal IVIGs are supposed to be immunosuppressive at doses in the range of $2 \mathrm{~g}$ per $\mathrm{kg}$ of recipient body weight. Given that COVID-19 largely resembles an autoimmune disorder in the late stages, 
IVIGs are presumed to act as an immune modulator by dampening the excessive immune response to SARS-CoV-2 which drives pathology [33,34]. A systematic review and metaanalysis by Xiang and colleagues on three clinical trials and three cohort studies [12] found that the effect of IVIG was associated with the severity of COVID-19, as it was highest in the critical subgroup. Our updated systematic review, performed on a higher number of studies and including more patients, gave different results. Although the length of hospitalization was significantly reduced in the IVIG group versus controls, a subgroup analysis showed that this effect was present only in patients with moderate disease. Regarding the main outcome "mortality", the use of IVIG was not associated with a significantly reduced risk of death, independently of COVID-19 severity or type of study (RCT or non-RCT). Such results are in accordance with a recently published living systematic review and network meta-analysis [35].

The majority of trials included in this systematic review were judged to be at high risk or at unclear risk of bias in many of the items of the ROB tool for RCTs and the ROBIN-1 tool for non-RCTs. Of the four RCTs, three were at high risk of performance (open-label trials), three were at unclear risk of detection bias (because it was unclear if the assessor was blinded to treatment allocation) and two at unclear risk of selection bias (because no clear information on allocation concealment was provided). Of the six non-RCTs, four were judged at high risk and two at unclear risk of confounding bias; three were judged at high risk and one at unclear risk of selection bias; all the non-RCTs were judged at unclear risk of bias for the domain bias in the measurement classification of interventions due to the retrospective nature of these studies. Moreover, considering the observed heterogeneity and imprecision in the effect size of the outcomes analyzed, the level of certainty of the available evidence was graded as low or very low. Another potential bias of this systematic review was the wide heterogeneity of IVIG doses in different studies, ranging from 0.1 to $1 \mathrm{~g} / \mathrm{kg} /$ day. It is therefore possible that sub-immunosuppressive doses have diluted the beneficial effect of fully immunosuppressive doses in the meta-analysis.

Adverse events were reported inconsistently and only in 4 of the 10 selected trials. Although overall adverse events and serious adverse events were rarely reported either in IVIG recipients or controls, the available evidence was graded as very low level of certainty due to inconsistency (small number of events and participants) and serious risk of bias.

In conclusion, although IVIGs appeared to be safe in COVID-19 patients, their use did not result in a significant reduction in mortality. Thus, the results of this systematic review and meta-analysis do not support the use of high-dose IVIG in COVID-19 patients.

Despite the initial signs of heterologous immunity to SARS-CoV-2 from previous seasonal coronavirus infection [36,37], pre-pandemic sera have been shown to be devoid of neutralizing activity [38], making the occurrence of neutralizing activity extremely unlikely in lots manufactured from plasma collected before 2021. However, the situation is rapidly evolving, with most plasma donors worldwide becoming seropositive because of convalescence and/or vaccination. Baxter reported seropositivity in lots released since September 2020. From there, values steadily increased, in correlation with the cumulative COVID-19 incidence, to reach a mean of $36.7 \mathrm{IU} / \mathrm{mL}$, and 93\% of lots were positive by January 2021. Extrapolating the correlation, the authors estimated that IVIGs could have reached an anti-SARS-CoV-2 potency of $\sim 400 \mathrm{IU} / \mathrm{mL}$ (i.e., a dose similar to that contained in a CCP unit) by July 2021. Therefore, further trials evaluating the last batches of IVIG are needed to assess whether the addition of anti-SARS-CoV-2 nAbs to their immunomodulatory effects will translate into a higher clinical efficacy.

Supplementary Materials: The following are available online at https:/ /www.mdpi.com/article/10 .3390 / vaccines10010094/s1, Supplementary File S1: Risk of bias tables. Supplementary File S2: Risk of bias graphs and forest plots of comparison.

Author Contributions: D.F. conceived the manuscript and wrote the first draft. M.F. wrote the first draft, extracted data and revised the protocol and the final version of the manuscript. M.C. wrote the first draft of the PROSPERO protocol and of the manuscript, extracted data and performed quality 
assessment and statistical analyses. M.T. revised the final version. All authors have read and agreed to the published version of the manuscript.

Funding: This research received no external funding.

Institutional Review Board Statement: Not applicable.

Informed Consent Statement: Not applicable.

Conflicts of Interest: The authors declare no conflict of interest.

\begin{abstract}
Abbreviations
IVIG: intravenous immunoglobulins; COVID-19: coronavirus disease 2019; SARS-CoV-2: severe acute respiratory syndrome coronavirus 2; CCP: COVID-19 convalescent plasma; HS: hyperimmune serum.
\end{abstract}

\title{
References
}

1. Wang, D.; Hu, B.; Hu, C.; Zhu, F.; Liu, X.; Zhang, J.; Wang, B.; Xiang, H.; Cheng, Z.; Xiong, Y.; et al. Clinical Characteristics of 138 Hospitalized Patients With 2019 Novel Coronavirus-Infected Pneumonia in Wuhan, China. JAMA 2020, 323, 1061-1069. [CrossRef] [PubMed]

2. $\quad \mathrm{Wu}, \mathrm{Z}$;; McGoogan, J.M. Characteristics of and Important Lessons From the Coronavirus Disease 2019 (COVID-19) Outbreak in China: Summary of a Report of 72314 Cases From the Chinese Center for Disease Control and Prevention. JAMA 2020, 323, 1239-1242. [CrossRef]

3. WHO. Coronavirus Disease (COVID-19). Available online: https://www.who.int/emergencies/diseases/novel-coronavirus-2019 (accessed on 31 August 2021).

4. Tobaiqy, M.; Qashqary, M.; Al-Dahery, S.; Mujallad, A.; Hershan, A.; Kamal, M.; Helmi, N. Therapeutic management of patients with COVID-19: A systematic review. Infect. Prev. Pract. 2020, 2, 100061. [CrossRef]

5. Heustess, A.M.; Allard, M.A.; Thompson, D.K.; Fasinu, P.S. Clinical Management of COVID-19: A Review of pharmacological treatment options. Pharmaceuticals 2021, 14, 520. [CrossRef] [PubMed]

6. Franchini, M.; Liumbruno, G.M.; Piacentini, G.; Glingani, C.; Zaffanello, M. The three pillars of COVID-19 convalescent plasma therapy. Life 2021, 11, 354. [CrossRef]

7. Focosi, D.; Franchini, M. COVID-19 convalescent plasma therapy: Hit fast, hit hard! Vox Sang. 2021, 116, 935-942. [CrossRef] [PubMed]

8. Wang, J.-T.; Sheng, W.-H.; Fang, C.-T.; Chen, Y.-C.; Wang, J.-L.; Yu, C.-J.; Chang, S.-C.; Yang, P.-C. Clinical manifestations, laboratory findings, and treatment outcomes of SARS patients. Emerg. Infect. Dis. 2004, 10, 818-824. [CrossRef]

9. Liu, X.; Cao, W.; Li, T. High-Dose Intravenous Immunoglobulins in the Treatment of Severe Acute Viral Pneumonia: The Known Mechanisms and Clinical Effects. Front. Immunol. 2020, 11, 1660. [CrossRef]

10. Soy, M.; Keser, G.; Atagündüz, P.; Tabak, F.; Atagündüz, I.; Kayhan, S. Cytokine storm in COVID-19: Pathogenesis and overview of anti-inflammatory agents used in treatment. Clin. Rheumatol. 2020, 39, 2085-2094. [CrossRef] [PubMed]

11. Yaqinuddin, A.; Ambia, A.R.; Elgazzar, T.A.; AlSaud, M.B.M.; Kashir, J. Application of intravenous immunoglobulin (IVIG) to modulate inflammation in critical COVID-19-A theoretical perspective. Med. Hypotheses 2021, 151, 110592. [CrossRef]

12. Xiang, H.R.; Cheng, X.; Li, Y.; Luo, W.W.; Zhang, Q.Z.; Peng, W.X. Efficacy of IVIG (intravenous immunoglobulin) for corona virus disease 2019 (COVID-19): A meta-analysis. Int. Immunopharmacol. 2021, 96, 107732. [CrossRef]

13. Moradimajd, P.; Samaee, H.; Sedigh-Maroufi, S.; Kourosh-Aami, M.; Mohsenzadagan, M. Administration of intravenous immunoglobulin in the treatment of COVID-19: A review of available evidence. J. Med. Virol. 2021, 93, 2675-2682. [CrossRef]

14. Higgins, J.P.T.; Green, S. (Eds.) Cochrane Handbook for Systematic Reviews of Interventions-Version 5.1.0 [Updated March 2011]. The Cochrane Collaboration: London, UK, 2011. Available online: www.handbook.cochrane.org (accessed on 1 December 2021).

15. Reeves, B.C.; Deeks, J.J.; Higgins, J.P.T.; Wells, G.A. Chapter 13: Including non-randomized studies. In Cochrane Handbook for Systematic Reviews of Interventions Version 5.1.0 (Updated March 2011); Higgins, J.P.T., Green, S., Eds.; The Cochrane Collaboration: London, UK, 2011. Available online: www.handbook.cochrane.org (accessed on 1 December 2021).

16. Sterne, J.A.C.; Hernán, M.A.; McAleenan, A.; Reeves, B.C.; Higgins, J.P.T. Chapter 25: Assessing risk of bias in a non-randomized study. In Cochrane Handbook for Systematic Reviews of Interventions Version 6.0 (Updated July 2019); Higgins, J.P.T., Thomas, J., Chandler, J., Cumpston, M., Li, T., Page, M.J., Welch, V.A., Eds.; Cochrane: London, UK, 2019. Available online: www.training. cochrane.org/handbook (accessed on 1 December 2021).

17. Sterne, J.A.C.; Hernán, M.A.; Reeves, B.C.; Savović, J.; Berkman, N.D.; Viswanathan, M.; Henry, D.; Altman, D.G.; Ansari, M.T.; Boutron, I.; et al. ROBINS-I: A tool for assessing risk of bias in non-randomised studies of interventions. BMJ 2016, 355, 4-10. [CrossRef] [PubMed]

18. Higgins, J.; Thompson, S.; Deeks JAltman, D.T.I. Measuring inconsistency in meta-analyses. BMJ 2003, 32, 557-560. [CrossRef] [PubMed] 
19. Schünemann, H.J.; Oxman, A.D.; Higgins, J.P.; Vist, G.E.; Glasziou, P.; Guyatt, G.H. Chapter 11: Presenting results and 'Summary of findings' tables. In Cochrane Handbook for Systematic Reviews of Interventions Version 5.1.0 (Updated March 2011); Higgins, J.P.T., Green, S., Eds.; The Cochrane Collaboration: London, UK, 2011. Available online: www.handbook.cochrane.org (accessed on 1 December 2021).

20. Guyatt, G.H.; Oxman, A.D.; Kunz, R.; Vist, G.E.; Falck-Ytter, Y.; Schünemann, H.J. What is 'quality of evidence' and why is it important to clinicians? BMJ 2008, 336, 995-998. [CrossRef]

21. Omma, A.; Erden, A.; Armağan, B.; Güven, S.C.; Karakaş, Ö.; Şahiner, E.S.; Erdem, D.; Izdeş, S.; Ateş, I.; Küçükşahin, O. A single center experience of intravenous immunoglobulin treatment in Covid-19. Int. Immunopharmacol. 2021, $98,107891$. [CrossRef] [PubMed]

22. Xie, Y.; Cao, S.; Dong, H.; Li, Q.; Chen, E.; Zhang, W.; Yang, L.; Fu, S.; Wang, R. Effect of regular intravenous immunoglobulin therapy on prognosis of severe pneumonia in patients with COVID-19. J. Infect. 2020, 81, 318-356. [CrossRef] [PubMed]

23. Cao, W.; Liu, X.; Bai, T.; Fan, H.; Hong, K.; Song, H.; Han, Y.; Lin, L.; Ruan, L.; Li, T. High-Dose Intravenous Immunoglobulin as a therapeutic option for deteriorating patients with Coronavirus Disease 2019. Open Forum Infect. Dis. 2020, 7, ofaa102. [CrossRef]

24. Esen, F.; Özcan, P.E.; Orhun, G.; Polat, Ö.; Anaklı, İ.; Alay, G.; Tuna, V.; Çeliksoy, E.; Kılıç, M.; Mercan, M.; et al. Effects of adjunct treatment with intravenous immunoglobulins on the course of severe COVID-19: Results from a retrospective cohort study. Curr. Med. Res. Opin. 2021, 37, 543-548. [CrossRef] [PubMed]

25. Gharebaghi, N.; Nejadrahim, R.; Mousavi, S.J.; Sadat-Ebrahimi, S.R.; Hajizadeh, R. The use of intravenous immunoglobulin gamma for the treatment of severe coronavirus disease 2019: A randomized placebo-controlled double-blind clinical trial. BMC Infect. Dis. 2020, 20, 786. [CrossRef]

26. Hou, X.; Tian, L.; Zhou, L.; Jia, X.; Kong, L.; Xue, Y.; Hao, H.; Meng, X.; Zhang, F.; Dong, X. Intravenous immunoglobulin-based adjuvant therapy for severe COVID-19: A single-center retrospective cohort study. Virol. J. 2021, 18, 101. [CrossRef]

27. Huang, C.; Fei, L.; Li, W.; Xu, W.; Xie, X.; Li, Q.; Chen, L. Efficacy evaluation of intravenous immunoglobulin in non-severe patients with COVID-19: A retrospective cohort study based on propensity score matching. Int. J. Infect. Dis. 2021, 105, 525-531. [CrossRef] [PubMed]

28. Liu, J.; Chen, Y.; Li, R.; Wu, Z.; Xu, Q.; Li, Z.; Annane, D.; Feng, H.; Huang, S.; Guo, J.; et al. Intravenous immunoglobulin treatment for patients with severe COVID-19: A retrospective multicentre study. Clin. Microbiol. Infect. 2021, 27, 1488-1493. [CrossRef]

29. Raman, R.S.; Barge, V.B.; Kumar, D.A.; Dandu, H.; Kartha, R.R.; Bafna, V.; Aravinda, V.T.; Raghuram, T.C. A Phase II Safety and Efficacy Study on Prognosis of Moderate Pneumonia in Coronavirus Disease 2019 Patients With Regular Intravenous Immunoglobulin Therapy. J. Infect. Dis. 2021, 223, 1538-1543. [CrossRef] [PubMed]

30. Sakoulas, G.; Geriak, M.; Kullar, R.; Greenwood, K.L.; Habib, M.; Vyas, A.; Ghafourian, M.; Dintyala, V.N.K.; Haddad, F. Intravenous Immunoglobulin plus methylprednisolone mitigate respiratory morbidity in Coronavirus Disease 2019. Crit. Care Explor. 2020, 2, e0280. [CrossRef]

31. Shao, Z.; Feng, Y.; Zhong, L.; Xie, Q.; Lei, M.; Liu, Z.; Wang, C.; Ji, J.; Liu, H.; Gu, Z.; et al. Clinical efficacy of intravenous immunoglobulin therapy in critical ill patients with COVID-19: A multicenter retrospective cohort study. Clin. Transl. Immunol. 2020, 9, e1192. [CrossRef]

32. Tabarsi, P.; Barati, S.; Jamaati, H.; Haseli, S.; Marjani, M.; Moniri, A.; Abtahian, Z.; Dastan, A.; Yousefian, S.; Eskandari, R.; et al. Evaluating the effects of Intravenous Immunoglobulin (IVIg) on the management of severe COVID-19 cases: A randomized controlled trial. Int. Immunopharmacol. 2021, 90, 107205. [CrossRef] [PubMed]

33. Morgenlander, W.R.; Henson, S.N.; Monaco, D.R.; Chen, A.; Littlefield, K.; Bloch, E.M.; Fujimura, E.; Ruczinski, I.; Crowley, A.R.; Natarajan, H.; et al. Antibody responses to endemic coronaviruses modulate COVID-19 convalescent plasma functionality. J. Clin. Investig. 2021, 131, 146927. [CrossRef] [PubMed]

34. Greenbaum, U.; Klein, K.; Martinez, F.; Song, J.; Thall, P.F.; Ramdial, J.L.; Knape, C.; Aung, F.M.; Scroggins, J.; Knopfelmacher, A.; et al. High levels of common cold coronavirus antibodies in convalescent plasma are associated with improved survival in COVID-19 patients. Front. Immunol. 2021, 12, 675679. [CrossRef]

35. Siemieniuk, R.A.; Bartoszko, J.J.; Martinez, J.P.D.; Kum, E.; Qasim, A.; Zeraatkar, D.; Izcovich, A.; Mangala, S.; Ge, L.; Han, M.A.; et al. Antibody and cellular therapies for treatment of covid-19: A living systematic review and network metaanalysis. BMJ 2021, 374, n2231. [CrossRef] [PubMed]

36. Ng, K.W.; Faulkner, N.; Cornish, G.H.; Rosa, A.; Harvey, R.; Hussain, S.; Earl, C.; Wrobel, A.G.; Benton, D.J.; Roustan, C.; et al. Preexisting and de novo humoral immunity to SARS-CoV-2 in humans. Science 2020, 370, 1339-1343. [CrossRef] [PubMed]

37. Díez, J.-M.; Romero, C.; Gajardo, R. Currently available intravenous immunoglobulin contains antibodies reacting against severe acute respiratory syndrome coronavirus 2 antigens. Immunotherapy 2020, 12, 571-576. [CrossRef] [PubMed]

38. Focosi, D.; Rosellini, A.; Spezia, P.G.; Macera, L.; Lanza, M.; Paolicchi, A.; Biagini, D.; Baj, A.; Pistello, M.; Maggi, F. Lack of neutralizing activity in nonconvalescent sera, regardless of ABO blood group anti-A isoagglutin titer. JCV Plus 2021, 1, 100035. [CrossRef] 